\title{
Odor Coding in the Mammalian Olfactory Epithelium
}

\author{
Smija M. Kurian ${ }^{1}$; Rafaella G. Naressi ${ }^{2}$; Diogo Manoel ${ }^{1}$; Ann-Sophie Barwich ${ }^{3, *} ;$ Bettina Malnic ${ }^{2, *}$; \\ Luis R. Saraiva ${ }^{1,4,5,{ }^{*}}$
}

${ }^{1}$ Sidra Medicine, Doha, Qatar.

2 Department of Biochemistry, University of São Paulo, São Paulo, Brazil.

${ }^{3}$ Indiana University, Bloomington, IN, USA.

${ }^{4}$ Monell Chemical Senses Center, Philadelphia, USA.

${ }^{5}$ College of Health and Life Sciences, Hamad Bin Khalifa University, Doha, Qatar

* Correspondence and requests for materials should be addressed to A.S.B. (email: abarwich@iu.edu; twitter: @smellosopher), B.M. (email: bmalnic@iq.usp.br), or L.R.S. (email: saraivalmr@gmail.com; twitter: @saraivalab)

\begin{abstract}
Noses are extremely sophisticated chemical detectors allowing animals to use scents to interpret and navigate their environments. Odor detection starts with the activation of odorant receptors (ORs), expressed in mature olfactory sensory neurons (OSNs) populating the olfactory mucosa. Different odorants, or different concentrations of the same odorant, activate unique ensembles of ORs. This mechanism of combinatorial receptor coding provided a possible explanation as to why different odorants are perceived as having distinct odors. Aided by new technologies, several recent studies have found that antagonist interactions also play an important role in the formation of the combinatorial receptor code. These findings mark the start of a new era in the study of odorant-receptor interactions and add a new level of complexity to odor coding in mammals.
\end{abstract}

Keywords: Olfaction, odor coding, combinatorial code, odorant, receptor, antagonist, smell.

\section{Introduction}

\begin{abstract}
"I should think we might fairly gange the future of biological science, centuries ahead, by estimating the time it will take to reach a complete, comprehensive understanding of odor. It may not seem a profound enough problem to dominate all the life sciences, but it contains, piece by piece, all the mysteries."
\end{abstract}

\section{— Lewis Thomas}

Smelling starts with a sniff. The process of breathing in air into the nose floods the nasal cavity with myriad odorous molecules, or simply put, odorants. These molecules may smell pleasant, repulsive, or act as carriers of critical biological or ecological messages.

Odorants communicating vital biological information typically elicit behavioral and physiological changes in animals, thus playing a pivotal role in the survival and the propagation of the species ( $\mathrm{Li}$ and Liberles, 2015). The identity of these ecologically-relevant odorants varies greatly among different species, and ultimately drives evolutionary adaptations to distinct ecological niches (Bear, et al., 2016, Li, et al., 2013, Manoel, et al., 2019).
A major challenge in studying smell and odor-guided behaviors has been the understanding of the biological mechanisms that enable the discrimination of a large number of odor cues, which are typically presented to the animal's nose in virtually infinite combinations of mixtures and concentrations.

This review presents a brief historical description of the key findings and early challenges surrounding odor coding in the mammalian nose. It discusses how recent advances in olfactory neurobiology fundamentally inform our understanding of the interactions between odorants and their receptors in the nose, and how this knowledge impacts theories of odor perception.

\section{Organization of the mammalian olfactory system}

The peripheral olfactory system of most mammalian species involves two major olfactory organs: the olfactory mucosa (OM) located at the top of the nasal cavity and the vomeronasal organ (VNO) sitting at its base (Buck, 2012). The anatomical structure of the olfactory system can vary significantly between species, with some mammalian lineages (e.g., catarrhine 
Major cell types populating the mammalian olfactory mucosa

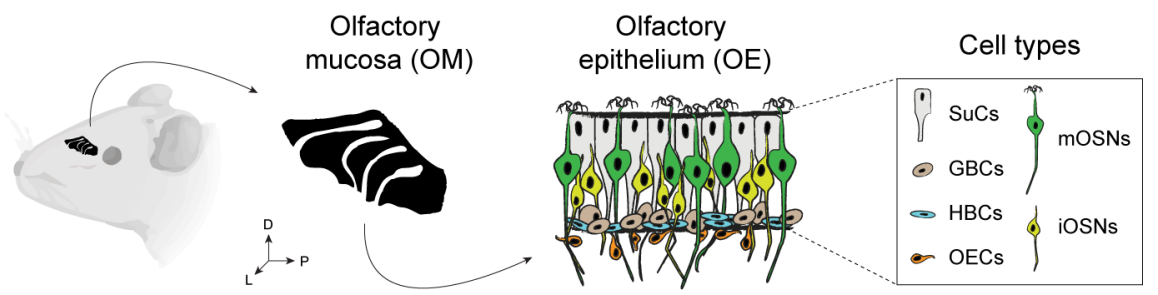

Figure 1 - The major cell types of the mammalian olfactory mucosa (OM). In mammals, the OM is composed by the olfactory epithelium (OE) and a submucosa. The OE is a pseudostratified epithelium composed mainly by sustentacular cells (SUCs), globose basal cells (GBCs), horizontal globose cells (HBCs), immature olfactory sensory neurons (iOSNs) and mature olfactory sensory neurons (mOSNs). The olfactory ensheathing cells (OECs) are an important cell type populating the submucosa.

monkeys, apes, and humans) lacking a VNO (Keverne, 1999), and other species (e.g., rodents) displaying additional olfactory organs, such as the septal organ of Masera and the Grueneberg ganglion (Barrios, et al., 2014, Ma, 2010).

Our focus is on the OM of the nose, which is composed of the olfactory epithelium (OE) and a submucosa. The $\mathrm{OE}$ is mainly populated by sustentacular cells, horizontal and globose basal cells, immature and mature olfactory sensory neurons (Fig. 1). The submucosa sitting below contains olfactory ensheathing cells, glandular and cavernous tissues, blood, and lymph vessels (Cuschieri and Bannister, 1975, Huard, et al., 1998, Morrison and Costanzo, 1992, Sharma, et al., 2019). Odorant reception occurs primarily in the OE via the mature olfactory sensory neurons (hereafter referred to as OSNs). This cell type, with its molecular and physiological architectures, thus is at the center of this review.

\section{Early challenges in understanding odor coding and the discovery of the odorant receptors}

$$
\begin{aligned}
& \text { "the olfactory imprint is collected in the mucosa by the peripheral } \\
& \text { expansion of the bipolar cells and is then transferred to the } \\
& \text { glomeruli where [...] cells from the molecular layer collect said } \\
& \text { imprint to raise it to the brain." } \\
& \text { - Santiago Ramón y Cajal }
\end{aligned}
$$

The two pioneers of neuroscience (and eternal rivals), Camillo Golgi and Santiago Ramón y Cajal, had described the basic neuroanatomical structure of the olfactory system in the late 19th century (Golgi, 1875, Ramón y Cajal, 1892). However, the concept of odorant receptors was considered only mid-20th century (Jones and Jones, 1953, Ottoson, 1954, Pauling, 1946, Skouby and Zilstorff-Pedersen, 1954, Sviridenko, 1951), while the genes encoding odorant receptors remained incognito for almost the entire 20th century.

The foundation for discovering the receptors genes was laid in the 1970s and '80s, with an increase in molecular studies that suggested a second messenger mechanism in olfaction. First, high adenylate cyclase activity was found in olfactory ciliary preparations of dissociated frog OSNs (Kurihara and Koyama, 1972, Pace, et al., 1985), a biochemical finding later confirmed physiologically (Firestein, et al., 1991). This data was followed by the identification of cyclic AMP (cAMP) as the secondary messenger in olfactory reception (Gesteland, 1976, Minor and Sakina, 1973). Contemporary technological developments, such as electrophysiological recordings, revealed that distinct odorants evoke distinguishable activation patterns in the OE (Kauer and Moulton, 1974, Mackay-Sim, et al., 1982), and even suggested the existence of multiple OSNs subtypes (Gesteland, 1976, Holley and MacLeod, 1977, Lancet, 1986, Sicard, 1985, Sicard and Holley, 1984).

Towards the end of the 1980s, mounting evidence pointed to G-protein coupled receptors (GPCRs) as the strongest candidates for odorant receptors (Lancet, 1986). Especially the identification of an olfactoryspecific gene coding for a $G \alpha$ protein (G $\alpha$ olf) and for a nucleotide-gated channel indicated that odorant activation involved G-protein mediated production of cAMP (Dhallan, et al., 1990, Jones and Reed, 1989). Around the same time, experiments using dissociated newt OSN provided evidence of intracellular calcium signaling during odorant binding. These experiments further implied a link to the mechanism of adenylate cyclase or gating of ion channels (Kurahashi and Shibuya, 1990).

The path looked paved for the discovery of the odorant receptors. Still, their identification as GPCRs would take several more years before transforming the field 
(Buck and Axel, 1991, Firestein, et al., 2014). Notable about this discovery was Buck's ingenious experimental design, which revealed a crucial feature of the OR family that would expand understanding of GPCRs: the mosaic character of the OR multigene family. ORs are highly conserved throughout evolution while also exhibiting striking structural diversity across their members. Instead of being defined by a specific set of shared amino acid sequences, the OR family relation is cross-cutting, meaning members share different sequences with various other members.

The mosaic character of OR genes had also made their discovery impracticable (Barwich, 2020, Buck, 2004). The standard discovery method of new gene families at the time was PCR. However, the amplification of genetic material with the known GPCR primer pair failed. Buck's use of RNA instead of DNA in combination in tandem with her design of 11 degenerate primers, amplifying related but not identical sequences (based on Buck's interest in genetic diversification), yielded the jackpot. Mammalian odorant receptors turned out to be the largest multigene family in the mammalian genome, containing $\sim 400$ intact genes in humans, $\sim 1100$ in mouse and $\sim 2000$ in elephants (Godfrey, et al., 2004, Malnic, et al., 2004, Niimura, et al., 2014, Zhang and Firestein, 2002).

\section{Other chemosensory receptors in the $\mathrm{OE}$}

Since the discovery of the OR gene family in 1991, other evolutionary conserved families of chemosensory receptor genes were found to be expressed in the mammalian $\mathrm{OE}$, including the trace-amine associated receptors (TAARs), two guanylyl cyclases (GUCY2D and GUCY1B2), and the membrane spanning 4-pass A (MS4A) receptors (Bear, et al., 2016, Fulle, et al., 1995, Greer, et al., 2016, Horowitz, et al., 2014, LeindersZufall, et al., 2007, Liberles and Buck, 2006, Omura and Mombaerts, 2015, Saraiva, et al., 2015b, Saraiva, et al., 2019). These 'atypical' receptors feature in other reviews in this issue, or were recently covered in other review articles.

\section{Odorant receptor expression in the $\mathrm{OE}$}

Following the discovery of the ORs, Buck and Axel's laboratories deepened research into OR genetics and wiring. One topic of main interest were the expression patterns exhibited by this remarkable gene family in the OE. By performing RNA in situ hybridization experiments, they found that OSNs expressing the same OR gene are randomly distributed within spatially restricted zones in the OE (Fig. 2a) (Ressler, et al., 1993, Vassar, et al., 1993).

\section{a Zonal expression of ORs in the OE}

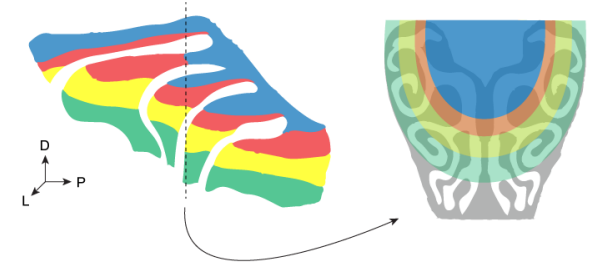

b 'one neuron - one receptor' rule'

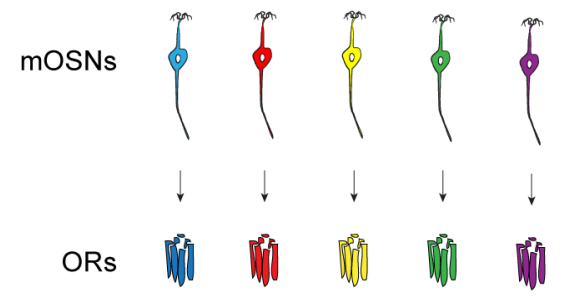

c Unequal expression of ORs in the OE

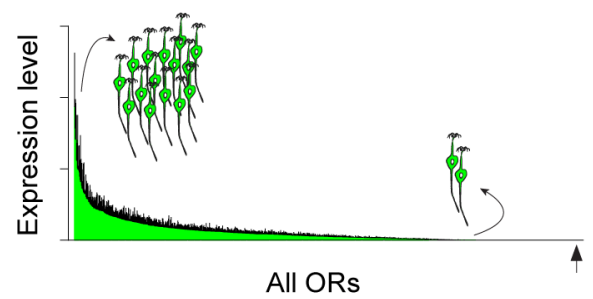

Figure 2 - Expression patterns of odorant receptors (ORs) in the olfactory epithelium (OE). (a) In the nose, mature olfactory sensory neurons (mOSNs) expressing the same OR gene are stochastically distributed within a spatially restricted area of the OE, also known as a 'zone'. Early studies identified 4 non-overlapping OR expression zones, but later studies identified as many as 9-12 partially overlapping zones. In the schematic, the 4 non-overlapping OR expression zones (blue, red, yellow, and green colors) are shown: left panel, lateral view of the olfactory mucosa (OM); right panel, a coronal section of the OM. (b) In the nose, each mOSN expresses one allele of a single OR gene. This type of expression became known in the field as the 'one neuron - one receptor rule'. (c) Recent RNA-seq experiments showed that most intact ORs are expressed in the $O E$ across a large dynamic range, with only a minority being expressed at very high levels. As measured by RNAseq, the abundance level of a given ORs in the $O E$ correlates perfectly to the number of OSNs expressing it.

Other studies confirmed the existence of different spatial patterns of expression, or zones, for mammalian 
ORs. However, the exact number of zones in the OE and their physiological function remains in debate (Bashkirova, et al., 2020, Coppola, et al., 2019, Horowitz, et al., 2014, Miyamichi, et al., 2005, Tan and Xie, 2018, Zapiec and Mombaerts, 2020).

Another significant breakthrough in understanding how OR genetics determine the wiring of the olfactory pathway arrived with two additional studies. These studies revealed that each OSN expresses only one allele of a single OR gene (Chess, et al., 1994, Malnic, et al., 1999). These findings led to the 'one neuron - one receptor rule' (Fig. 2b), and several subsequent studies provided additional support to the monogenic and monoallelic expression of OR genes in the OE $(\mathrm{Li}$, et al., 2004, Serizawa, et al., 2003, Shykind, et al., 2004, Tian and Ma, 2008, Tietjen, et al., 2005, Tietjen, et al., 2003). More recently, studies using single-cell RNAsequencing (RNA-seq) have shown that while immature OSNs express low levels of multiple OR genes, the vast majority of mature OSNs express a single OR gene at high levels (Hanchate, et al., 2015, Saraiva, et al., 2015b, Tan, et al., 2015). These results indicate that singular OR gene expression is achieved during the differentiation of the OSN, and further contributes to understanding the mechanisms of OR gene choice (Nagai, et al., 2016).

Another notable feature of ORs, is that their expression level in the OE can differ dramatically, with some receptors being up to 300 -fold more abundant than others (Bressel, et al., 2016, Khan, et al., 2011, Rodriguez-Gil, et al., 2015, Young, et al., 2003, Zhang, et al., 2004). In line with these results, recent RNA-seq studies performed in the $\mathrm{OE}$ of several mammalian species (mouse, rat, dog, marmoset, macaque, and human) have shown that the vast majority of ORs (up to $98.9 \%$ in mouse) are expressed across a large dynamic range of abundance in the $\mathrm{OE}$, and that $\mathrm{OR}$ gene expression levels correlates with the number of OSNs expressing the same OR (Fig. 2c) (Ibarra-Soria, et al., 2014, Ibarra-Soria, et al., 2017, Saraiva, et al., 2015a, Saraiva, et al., 2015b, Saraiva, et al., 2019). These studies also indicated that RNA-seq is not only a highly sensitive technique to detect mRNA from ORs, but it also serves as an accurate high-throughput tool to catalog OSN subtype diversity.

\section{A solution to a number's problem - the 'combinatorial receptor code'}

The total number of stimuli recognized and discriminated by the olfactory system remains to be determined. A recent study estimated that humans can discriminate at least 1.72 trillion odors (Bushdid, et al., 2014). This number was contested and estimated to constitute the upper bound instead (Gerkin and Castro, 2015, Meister, 2015). In either scenario, the numbers of odorants detected and discriminated by the nose vastly exceed the number of intact ORs present in any given species (Niimura, et al., 2014). So, how does the olfactory system solve this multifactorial problem?

Initial experiments, recording from single OSNs in the OE, revealed that each OSN responds selectively to more than one odorant and that individual odorants activate unique sets of OSNs (Firestein, et al., 1993, Sato, et al., 1994, Sicard and Holley, 1984). In 1999, experiments combining calcium imaging and single-cell RT-PCR allowed, for the first time, the identification of the ORs expressed in OSNs - specifically OSNs activated by a group of aliphatic odorants which were tested at different concentrations (Malnic, et al., 1999). These results were revolutionary, as they provided concrete evidence that different odorants, or different concentrations of the same odorant, are recognized by a unique combination of multiple ORs. In other words, each concentration of a given odorant generates its own 'combinatorial receptor code' in the OE (Fig. 3a).

Roughly a decade later, a study performed in the mouse OE analyzed the responses of 3000 mature OSNs to 125 different odorants, representing 375,000 possible OSN/OR-odorant pairings (Nara, et al., 2011). This large-scale study still constitutes the most comprehensive analysis of odorant response profiles in OSNs/ORs. It yielded three novel and significant findings about odor coding in the OE. First, OSNs/ORs repertoires exhibit an extraordinary diversity as well as bias, in odorant recognition. Second, most OSNs/ORs are narrowly tuned (i.e., detect one or a small number of structurally related odorants), although broadly tuned OSNs (i.e., responding to a large number of odorants) are also present in the OE. Third, the vast majority of odorants elicit a unique combinatorial activation code, containing both narrowly and broadly tuned OSNs/ORs.

Together, these results expanded our understanding of odorant detection and odor coding in the OE. In particular, these studies offered a potential explanation why different odorants exhibit distinct odors, including 
odorants that are structurally very similar yet diverge in sensory quality. Importantly, this combinatorial strategy deployed by OSNs, or ORs, has since been validated by many other studies and mammalian species (Araneda, et al., 2000, Araneda, et al., 2004, Duchamp-Viret, et al., 1999, Gonzalez-Kristeller, et al., 2015, Hamana, et al., 2003, Hu, et al., 2020, Jiang, et al., 2015, Kajiya, et al., 2001, McClintock, et al., 2014, Nara, et al., 2011, Oka, et al., 2004a, Oka, et al., 2004b, Saito, et al., 2009, SatoAkuhara, et al., 2016, von der Weid, et al., 2015).

\section{Odor mixtures and odorant-OR interactions in the OE}

Combinatorial coding helped to model the interaction of individual odorants with receptor repertoires. However, in natural environments, the olfactory system is exposed to complex mixtures of odorants, not to single odorants. Recent studies thus started to focus on mixture perception by investigating receptor responses to blends of multiple odorants.

These experiments now shed a markedly new light on explanations of odor coding at the peripheral level. Specifically, results show that peripheral odor coding involves odorants acting on receptors as agonists, antagonists, inverse agonists, partial agonists, and even have a synergistic effect (de March, et al., 2020, Inagaki, et al., 2020, McClintock, et al., 2020, Pfister, et al., 2020, Reddy, et al., 2018, Xu, et al., 2020, Zak, et al., 2020).

These advancements were fueled by technological progress. Notable here was the introduction of a new microscopy technique: Swept Confocally Aligned Planar Excitation (SCAPE). In a breakthrough study of the Firestein lab, SCAPE was used to test odor responses in OSNs of genetically engineered mice that expressed a calcium-sensitive fluorescent protein (GCaMP6f). Notably, this study measured odorant responses in intact epithelium tissue in real-time to analyze receptor responses in individual OSNs across a collection of $\sim 10,000$ cells (Xu, et al., 2020)

Observations of mixture coding yielded two notable effects: the suppression as well as the enhancement in individual cell responses. On the one hand, constituting suppression effects, responses to a mixture of three odorants (acetophenone, benzyl acetate, and citral) showed that some OSNs that responded predominantly to acetophenone when administered individually, had their responses to acetophenone suppressed or completely inhibited when exposed to the ternary odorant mixture. On the other hand, revealing enhancement effects, another subset of OSNs that initially yielded small responses to acetophenone and benzyl acetate alone, showed increased responses when a mix of the two odorants was added. Additionally, a group of OSNs that did not respond to citral showed a higher response to acetophenone when citral was included in the mix, which can be interpreted as a sign of synergistic effects. Synergistic effects were also found in another study, which analyzed responses to odorant mixtures via in vivo two-photon imaging of OSNs expressing GCaMP3. Here, the synergistic effects were seen preferentially for low concentrations of odorants in the mix. In comparison, antagonism was predominant for higher concentrations of odorants in the mixture (Inagaki, et al., 2020). These synergistic effects could indicate an allosteric mechanism, even though this type of modulation has rarely been reported for Class A GPCRs. Yet odorant binding to an allosteric site might explain, for example, why a receptor that did not respond to three individual odorants is active when exposed to a mixture of all three (Xu, et al., 2020).

A critical part of this revised model of odorant-receptor interaction is a markedly theoretical element. The SCAPE study presents a possible answer to the inherent neurocomputational challenge arising from combinatorial coding at the periphery: How does the brain discriminate different complex mixtures from widespread and overlapping receptor activity? Antagonistic modulation at the receptor level would facilitate sparse coding resulting in less ambiguous signal patterns. Aromatic blends, such as coffee or roses, are composed of hundreds of different components. The combinatorial code allows humans to detect various odorant features in such mixtures and respond to a complex and, in its constituents, unpredictable chemical environment. However, with combinatorial activation alone, receptor activation patterns quickly overlapped to form a broad and smudged signal, which would lose its distinctiveness. Modulation, antagonistic and allosteric, facilitates a unique receptor code for the discrimination of complex mixtures. Less, literally, can be more.

Another study used calcium imaging of dissociated mouse OSNs to analyze how indole sensitive cells respond to a mixture of indole and other odorants (Pfister, et al., 2020). The data demonstrated dosedependent inhibition of the responses to indole by a variety of structurally diverse odorants. The ORs expressed by the indole responsive OSNs, as part of the 
a

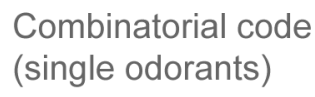

Combinatorial code

(single odorants)

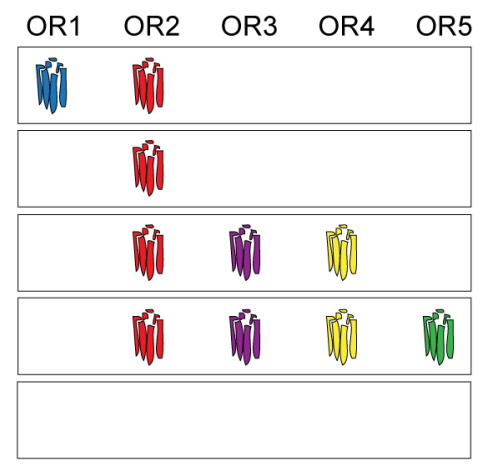

b Modulated combinatorial code (odorants as part of a mixture)

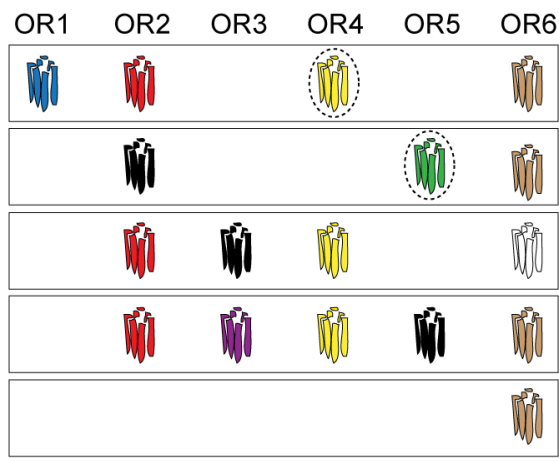

Odorant interactions:

10 Agonism Synergism

Antagonism

Inverse agonism

Constitutively active

Figure 3 - Modulation of the olfactory combinatorial code. In the mammalian nose, odorants are detected by ORs in a combinatorial fashion. In other words, one odorant can activate multiple ORs, and each OR can detect more than one odorant. (a) When the combinatorial code was first established, each OR was tested against a given concentration of a single odorant, and only agonist interactions were analyzed. (b) Recent studies analyzed the responses of ORs to odorants as part of odor mixtures, and found that odorants in addition to their agonist role, can also serve as modulators (antagonists, inverse agonists, partial agonists and synergistic ligands) to OR activity.

same OR subfamily and additional OR paralogs, were identified by single-cell RNA-seq and characterized in a heterologous expression system. The activation profiles of these receptors to a large library of structurally diverse odorants $(\sim 800)$ showed that $\sim 50 \%$ of the odorants in the library were able to antagonize at least one of these ORs, with some of them antagonizing one single OR and others antagonizing multiple ORs. Notably, the results indicate that antagonism by odorants may also occur in a combinatorial fashion. Overall, mathematical modeling of dose-response curves by antagonizing odorants remain consistent with competitive binding, while the authors do not exclude that some antagonist odorants could act noncompetitively (allosterically) (Pfister, et al., 2020).

In vivo experiments in freely behaving mice indicated that responses of all indole sensitive ORs are inhibited when the agonist was mixed with $\alpha$-ionone. In contrast, a different group of ORs proved responsive to the mixture (McClintock, et al., 2020). The same type of in vivo experiments, now followed by confirmation by in vitro expression of the ORs, demonstrated that the odorant whiskey lactone suppressed isoamyl acetate responses from a fraction of OSNs responsive to isoamyl acetate alone (de March, et al., 2020). Comparable antagonistic effects were found in binary mixtures containing undecanal and bourgenal. These experiments further registered inverse agonism, suppressing the receptors' basal activity upon exposure to bourgeonal, as well as partial agonism (de March, et al., 2020).

Antagonism proved the most common modulator of olfactory responses. However, the presence of inverse agonism (when an odorant binds to the receptor and decreases the receptor's basal activity) both in vivo and heterologous assays, remains notable (de March, et al., 2020, Inagaki, et al., 2020, Pfister, et al., 2020). An odorant can perform different causal roles, both as an agonist to one OR and an inverse agonist to another $\mathrm{OR}$, as seen in heterologous essays (Inagaki, et al., 2020). These results are further consistent with previous observations (Ache, et al., 1988, Araneda, et al., 2004, Bell, et al., 1987, Chaput, et al., 2012, Duchamp-Viret, et al., 2003, Münch, et al., 2013, Oka, et al., 2004b, Peterlin, et al., 2008, Rospars, et al., 2008, Sanz, et al., 2005, Shirokova, et al., 2005, Spehr, et al., 2003).

Collectively these studies reveal that modulation of odorant responses can begin peripherally, at the OR level, before the stimulus reaches the olfactory bulb. Odorants act as agonists to activate ORs in a combinatorial fashion, but also serve as modulators (antagonists, inverse agonists, partial agonists and synergistic ligands) to OR activity (Fig. 3b).

Modulation of the combinatorial code points to two central explanatory tenets relevant to current research in olfaction. First, modulation explains how the 
olfactory system deals with the discrimination of overlapping receptor repertoires in high-dimensional odorant mixtures. Second, it links molecular data with psychophysical studies that have documented the psychological equivalent of suppression and enhancement effects in mixture perception (Cain, 1975, Kay, et al., 2005, Laing, et al., 1984)

\section{Other Features of OR-ligand Interactions}

Additional mechanisms can further modulate OR responses or even inhibit odor perception, such as odorant-odorant metabolic interaction, enzymatic conversion or dilution of odor molecules by mucus occurs in the nasal cavity (Asakawa, et al., 2017, Hanser, et al., 2017, Ijichi, et al., 2019, Nagashima and Touhara, 2010). Moreover, odorant-binding proteins, a class of lipocalin proteins secreted by nasal glands and capable of binding to odorant molecules, are present in vertebrates' mucus. However, their exact physiological role in olfaction still remains mostly unknown (Bignetti, et al., 1985, Briand, et al., 2002, Flower, 1996, Heydel, et al., 2013, Pevsner, et al., 1986, Tegoni, et al., 2000). Future work will help elucidate how these additional mechanisms further shape OR-ligand interactions and contribute to odor perception.

\section{Concluding remarks}

How olfactory cues are translated into complex behavioral or physiological changes presents one of neuroscience's greatest mysteries. Odor coding at the periphery is central to solving this secret. Combinatorial coding and receptor modulation mechanisms reveal that odorant-binding at the periphery is not a passive interface that translates chemical data into electrical signals. These primary detection mechanisms actively structure the chemical data that reaches the brain. As Lettvin and colleagues had noted most famously for the visual system: the (frog's) retina performs computations in the first layer of input that renders the foundations for any subsequent signal computation model in the brain (Lettvin, et al., 1959). The same principle applies to olfaction. Therefore, it is imperative to model odor coding principles based on the odorant receptor's activity.

Odorant receptors are not ruled by the same mechanisms as the visual system. Odorants activate unique combinations of ORs in the OE. Some odorants can trigger a large number of ORs. Other odorants are less promiscuous and activate only a small number of ORs. The composition and sizes of these receptor codes for odorants also change with changes in odorant concentration. This initial information is thought to be subsequently processed and interpreted in the olfactory bulb and higher brain centers, leading to the different odor percepts. Mounting evidence now suggests that the first level of modulation of odorant responses already occurs in the OE. Interactions among various odorant components in a mixture can modulate and alter the combinatorial code to a particular odorant at the OR level, including concentration-dependent activity. These results bring a new level of complexity to olfactory coding, where a large number of receptors and odorants are involved and several possible combinations of odorants. The role of these modulatory interactions in odorant perception can be addressed in experiments that analyze how much exposure to odorant mixtures, compared to exposure to single odorants, can change olfactory-driven behaviors in mice.

Future experiments should consider these odorant interactions at the periphery and investigate remaining unanswered questions. Do some odorants covalently interact with receptors and modify their ligand binding sites? Or can odorants in a mixture interact one with another to produce new chemical structures? An additional factor to consider is the relative concentration of the odorant components within a scent. We know that while fragrances are composed of multiple odorants, some are predominant in concentration or intensity, or in volatility. According to the Laing limit (Laing and Francis, 1989, Laing, 1987), identifying single odorants in mixtures gets more difficult as the number of odorants increases. Recent research indicates that this limit may not link to a saturation of the receptor code but is caused by antagonistic effects.

These constitute relatively new and revolutionary insights. Experimental advances investigating concrete interactions of odorants and receptors were primarily driven by the recent advent of high-throughput technologies, such as discussed in this review (e.g., RNA-sequencing, SCAPE microscopy). The next years thus promise the generation of larger datasets in a markedly faster pace that will allows us to better model how receptor interactions shape odor coding. Combining these data with other large datasets from multidimensional behavioral phenotyping studies, chemoinformatics and deep learning, will facilitate the understanding of the functional impact of the 
combinatorial code and its modulation in odor-guided behavioral and physiological responses.

But the final frontier to cracking the olfactory code promises to be of a markedly theoretical nature, as recent studies on the odorant-receptor interactions foreshadow a paradigm shift. Thus far, the evidence gathered strongly suggests a first level of modulation of odorant responses through linear and non-linear interactions in the OE. Plus, recent studies with a medicinal chemistry approach have shown that OSNs do not categorize odorants as similar according to the principles of organic chemistry (Poivet, et al., 2016, Poivet, et al., 2018). In fact, they respond to features not even recognized by recent machine learning studies mapping odorants to perceptual categories, such as the recent study by Keller and colleagues (Keller, et al., 2017). As a result, any neural correlates of odor perception cannot be found by directly mapping chemical input structures onto neural activation patterns. Instead, the new task emerging is to determine the principles by which the olfactory system detects, encodes, permutates, and modulates its information starting with the mechanisms of odor coding right at the periphery.

\section{DECLARATIONS}

\section{Ethics approval and consent to participate}

This article does not contain any studies with human participants or animals performed by the authors.

\section{Consent for publication}

The authors have consented the study for publication.

\section{Competing interests}

The authors declare that they have no competing interests.

\section{FUNDING}

This work was supported by Sidra Medicine and Qatar National Research Fund (a member of Qatar Foundation) Program grant JSREP07-016-1-006 (awarded to LRS). BM and RGN supported by a grant from FAPESP (\#16/24471-0) and CAPES (88887.374907/2019-00), respectively. The findings herein reflect the work and are solely the responsibility of the authors.

\section{ACKNOWLEDGMENTS}

The authors thank the Saraiva Lab members for insightful discussions and critical reading of the manuscript.

\section{REFERENCES}

Ache BW, Gleeson RA, Thompson HA (1988) Mechanisms for mixture suppression in olfactory receptors of the spiny lobster. Chemical senses 13:425434

Araneda RC, Kini AD, Firestein S (2000) The molecular receptive range of an odorant receptor. Nat Neurosci 3:1248-1255

Araneda RC, Peterlin Z, Zhang X, Chesler A, Firestein $S$ (2004) A pharmacological profile of the aldehyde receptor repertoire in rat olfactory epithelium. J Physiol 555:743-756

Asakawa M, Fukutani Y, Savangsuksa A, Noguchi K, Matsunami H, Yohda M (2017) Modification of the response of olfactory receptors to acetophenone by CYP1a2. Scientific reports 7:10167

Barrios AW, Nunez G, Sanchez Quinteiro P, Salazar I (2014) Anatomy, histochemistry, and immunohistochemistry of the olfactory subsystems in mice. Front Neuroanat 8:63

Barwich AS (2020) What Makes a Discovery Successful? The Story of Linda Buck and the Olfactory Receptors. Cell 181:749-753

Bashkirova E, Monahan K, Campbell CE, Osinski JM, Tan L, Schieren I, Barnea G, Xie XS, Gronostajski RM, Lomvardas S (2020) Homeotic Regulation of Olfactory Receptor Choice via NFI-dependent Heterochromatic Silencing and Genomic Compartmentalization. bioRxiv 2020.2008.2030.274035

Bear DM, Lassance JM, Hoekstra HE, Datta SR (2016) The Evolving Neural and Genetic Architecture of Vertebrate Olfaction. Curr Biol 26:R1039-R1049

Bell GA, Laing DG, Panhuber H (1987) Odour mixture suppression: evidence for a peripheral mechanism in human and rat. Brain Res 426:8-18

Bignetti E, Cavaggioni A, Pelosi P, Persaud K, Sorbi R, Tirindelli R (1985) Purification and characterisation of 
an odorant-binding protein from cow nasal tissue. Eur J Biochem 149:227-231

Bressel OC, Khan M, Mombaerts P (2016) Linear correlation between the number of olfactory sensory neurons expressing a given mouse odorant receptor gene and the total volume of the corresponding glomeruli in the olfactory bulb. J Comp Neurol 524:199-209

Briand L, Eloit C, Nespoulous C, Bezirard V, Huet JC, Henry C, Blon F, Trotier D, Pernollet JC (2002) Evidence of an odorant-binding protein in the human olfactory mucus: location, structural characterization, and odorant-binding properties. Biochemistry 41:72417252

Buck L, Axel R (1991) A novel multigene family may encode odorant receptors: a molecular basis for odor recognition. Cell 65:175-187

Buck LB (2004) The search for odorant receptors. Cell 116:S117-119, 111 p following S119

Buck LB, and Bargmann, C. (2012) Smell and Taste: the Chemical Senses. In: Kandel E, Schwartz, J., Jessell, T., Siegelbaum, S., Hudspeth, A.J. (ed) Principles of Neuroscience. McGraw-Hill, New York, pp 712-742

Bushdid C, Magnasco MO, Vosshall LB, Keller A (2014) Humans can discriminate more than 1 trillion olfactory stimuli. Science 343:1370-1372

Cain WS (1975) Odor intensity: mixtures and masking. Chemical senses 1:339-352

Chaput MA, El Mountassir F, Atanasova B, ThomasDanguin T, Le Bon AM, Perrut A, Ferry B, DuchampViret P (2012) Interactions of odorants with olfactory receptors and receptor neurons match the perceptual dynamics observed for woody and fruity odorant mixtures. Eur J Neurosci 35:584-597

Chess A, Simon I, Cedar H, Axel R (1994) Allelic inactivation regulates olfactory receptor gene expression. Cell 78:823-834

Coppola DM, Fitzwater E, Rygg AD, Craven BA (2019) Tests of the chromatographic theory of olfaction with highly soluble odors: a combined electro-olfactogram and computational fluid dynamics study in the mouse. Biol Open 8:

Cuschieri A, Bannister LH (1975) The development of the olfactory mucosa in the mouse: light microscopy. J Anat 119:471-498 de March CA, Titlow WB, Sengoku T, Breheny P, Matsunami H, McClintock TS (2020) Modulation of the combinatorial code of odorant receptor response patterns in odorant mixtures. Mol Cell Neurosci 104:103469

Dhallan RS, Yau KW, Schrader KA, Reed RR (1990) Primary structure and functional expression of a cyclic nucleotide-activated channel from olfactory neurons. Nature 347:184-187

Duchamp-Viret P, Chaput MA, Duchamp A (1999) Odor response properties of rat olfactory receptor neurons. Science 284:2171-2174

Duchamp-Viret P, Duchamp A, Chaput MA (2003) Single olfactory sensory neurons simultaneously integrate the components of an odour mixture. Eur J Neurosci 18:2690-2696

Firestein S, Darrow B, Shepherd GM (1991) Activation of the sensory current in salamander olfactory receptor neurons depends on a $G$ protein-mediated cAMP second messenger system. Neuron 6:825-835

Firestein S, Greer C, Mombaerts P (2014) The molecular basis for odor recognition. Cell Annotated Classic.

. Cell

Firestein S, Picco C, Menini A (1993) The relation between stimulus and response in olfactory receptor cells of the tiger salamander. Journal of Physiology 468:1-10

Flower DR (1996) The lipocalin protein family structure and function. Biochemical Journal 318:1-14

Fulle HJ, Vassar R, Foster DC, Yang RB, Axel R, Garbers DL (1995) A receptor guanylyl cyclase expressed specifically in olfactory sensory neurons. Proceedings of the National Academy of Sciences of the United States of America 92:3571-3575

Gerkin RC, Castro JB (2015) The number of olfactory stimuli that humans can discriminate is still unknown. eLife 4:e08127

Gesteland RC (1976) Physiology of Olfactory Reception. In: LLinas R, Precht W (eds) Frog Neurobiology. Springer - Verlag, Heidelberg, pp 234250

Godfrey PA, Malnic B, Buck LB (2004) The mouse olfactory receptor gene family. Proceedings of the National Academy of Sciences of the United States of America 101:2156-2161 
Golgi C (1875) Sulla fina struttura del bulbi olfattorii. Rivista sperimentale di freniatria e medicina legale 1:207-241

Gonzalez-Kristeller DC, do Nascimento JB, Galante PA, Malnic B (2015) Identification of agonists for a group of human odorant receptors. Front Pharmacol $6: 35$

Greer PL, Bear DM, Lassance JM, Bloom ML, Tsukahara T, Pashkovski SL, Masuda FK, Nowlan AC, Kirchner R, Hoekstra HE, Datta SR (2016) A Family of non-GPCR Chemosensors Defines an Alternative Logic for Mammalian Olfaction. Cell 165:1734-1748

Hamana H, Hirono J, Kizumi M, Sato T (2003) Sensitivity-dependent hierarchical receptor codes for odors. Chemical senses 28:87-104

Hanchate NK, Kondoh K, Lu Z, Kuang D, Ye X, Qiu X, Pachter L, Trapnell C, Buck LB (2015) Single-cell transcriptomics reveals receptor transformations during olfactory neurogenesis. Science 350:1251-1255

Hanser HI, Faure P, Robert-Hazotte A, Artur Y, Duchamp-Viret P, Coureaud G, Heydel JM (2017) Odorant-odorant metabolic interaction, a novel actor in olfactory perception and behavioral responsiveness. Scientific reports 7:10219

Heydel JM, Coelho A, Thiebaud N, Legendre A, Le Bon AM, Faure P, Neiers F, Artur Y, Golebiowski J, Briand L (2013) Odorant-binding proteins and xenobiotic metabolizing enzymes: implications in olfactory perireceptor events. Anat Rec (Hoboken) 296:1333-1345

Holley A, MacLeod P (1977) Transduction et codage des informations olfactives chez les vertebres. J Physiol 73:725 - 828

Horowitz LF, Saraiva LR, Kuang D, Yoon KH, Buck LB (2014) Olfactory receptor patterning in a higher primate. The Journal of neuroscience : the official journal of the Society for Neuroscience 34:12241-12252

Hu XS, Ikegami K, Vihani A, Zhu KW, Zapata M, de March CA, Do M, Vaidya N, Kucera G, Bock C, Jiang Y, Yohda M, Matsunami H (2020) ConcentrationDependent Recruitment of Mammalian Odorant Receptors. eNeuro 7:

Huard JM, Youngentob SL, Goldstein BJ, Luskin MB, Schwob JE (1998) Adult olfactory epithelium contains multipotent progenitors that give rise to neurons and non-neural cells. J Comp Neurol 400:469-486
Ibarra-Soria X, Levitin MO, Saraiva LR, Logan DW (2014) The olfactory transcriptomes of mice. PLoS Genet 10:e1004593

Ibarra-Soria X, Nakahara TS, Lilue J, Jiang Y, Trimmer C, Souza MA, Netto PH, Ikegami K, Murphy NR, Kusma M, Kirton A, Saraiva LR, Keane TM, Matsunami H, Mainland J, Papes F, Logan DW (2017) Variation in olfactory neuron repertoires is genetically controlled and environmentally modulated. eLife 6:

Ijichi C, Wakabayashi H, Sugiyama S, Ihara Y, Nogi Y, Nagashima A, Ihara S, Niimura Y, Shimizu Y, Kondo K, Touhara K (2019) Metabolism of Odorant Molecules in Human Nasal/Oral Cavity Affects the Odorant Perception. Chemical senses 44:465-481

Inagaki S, Iwata R, Iwamoto M, Imai T (2020) Widespread Inhibition, Antagonism, and Synergy in Mouse Olfactory Sensory Neurons In Vivo. Cell reports 31:107814

Jiang Y, Gong NN, Hu XS, Ni MJ, Pasi R, Matsunami H (2015) Molecular profiling of activated olfactory neurons identifies odorant receptors for odors in vivo. Nat Neurosci 18:1446-1454

Jones DT, Reed RR (1989) Golf: an olfactory neuronspecific G-protein involved in odorant signal transduction. Science 244:790-795

Jones FN, Jones MH (1953) Modern Theories of Olfaction: A Critical Review. The Journal of Psychology 36:207-241

Kajiya K, Inaki K, Tanaka M, Haga T, Kataoka H, Touhara K (2001) Molecular bases of odor discrimination: Reconstitution of olfactory receptors that recognize overlapping sets of odorants. The Journal of neuroscience : the official journal of the Society for Neuroscience 21:6018-6025

Kauer JS, Moulton DG (1974) Responses of olfactory bulb neurones to odour stimulation of small nasal areas in the salamander. J Physiol (Lond) 243:717-737

Kay LM, Crk T, Thorngate J (2005) A redefinition of odor mixture quality. Behav Neurosci 119:726-733

Keller A, Gerkin RC, Guan Y, Dhurandhar A, Turu G, Szalai B, Mainland JD, Ihara Y, Yu CW, Wolfinger R, Vens C, Schietgat L, De Grave K, Norel R, Consortium DOP, Stolovitzky G, Cecchi GA, Vosshall LB, Meyer P (2017) Predicting human olfactory perception from chemical features of odor molecules. Science 355:820826 
Keverne EB (1999) The vomeronasal organ. Science 286:716-720

Khan M, Vaes E, Mombaerts P (2011) Regulation of the probability of mouse odorant receptor gene choice. Cell 147:907-921

Kurahashi T, Shibuya T (1990) Ca2+-dependent adaptive properties in the solitary olfactory receptor cell of the newt. Nature 515:261-268

Kurihara K, Koyama N (1972) High activity of adenyl cyclase in olfactory and gustatory organs. Biochem Biophys Res Commun 48:30 - 34

Laing D, Francis G (1989) The capacity of humans to identify odors in mixtures. Physiology \& behavior 46:809-814

Laing DG (1987) Coding of chemosensory stimulus mixtures. Ann N Y Acad Sci 510:61-66

Laing DG, Panhuber H, Willcox ME, Pittman EA (1984) Quality and intensity of binary odor mixtures. Physiology \& behavior 33:309-319

Lancet D (1986) Vertebrate olfactory reception. Ann Rev Neurosci 9:329-355

Leinders-Zufall T, Cockerham RE, Michalakis S, Biel M, Garbers DL, Reed RR, Zufall F, Munger SD (2007) Contribution of the receptor guanylyl cyclase GC-D to chemosensory function in the olfactory epithelium. Proceedings of the National Academy of Sciences of the United States of America 104:14507-14512

Lettvin JY, Maturana HR, McCulloch WS, Pitts WH (1959) What the frog's eye tells the frog's brain. . Proc Inst Radio Engr 1940-1951

Li J, Ishii T, Feinstein P, Mombaerts P (2004) Odorant receptor gene choice is reset by nuclear transfer from mouse olfactory sensory neurons. Nature 428:393-399

Li Q, Korzan WJ, Ferrero DM, Chang RB, Roy DS, Buchi M, Lemon JK, Kaur AW, Stowers L, Fendt M, Liberles SD (2013) Synchronous evolution of an odor biosynthesis pathway and behavioral response. Curr Biol 23:11-20

Li Q, Liberles SD (2015) Aversion and attraction through olfaction. Curr Biol 25:R120-129

Liberles SD, Buck LB (2006) A second class of chemosensory receptors in the olfactory epithelium. Nature 442:645-650

Ma M (2010) Multiple Olfactory Subsystems Convey Various Sensory Signals. In: Menini A (ed) The
Neurobiology of Olfaction. Frontiers in Neuroscience, Boca Raton (FL)

Mackay-Sim A, Shaman P, Moulton DG (1982) Topographic coding of olfactory quality: Odorantspeicfic patterns of epithelial responsivity in the Slamander. Journal of Neurophysiology 48:584-595

Malnic B, Godfrey PA, Buck LB (2004) The human olfactory receptor gene family. Proceedings of the National Academy of Sciences of the United States of America 101:2584-2589

Malnic B, Hirono J, Sato T, Buck LB (1999) Combinatorial receptor codes for odors. Cell 96:713723

Manoel D, Makhlouf M, Scialdone A, Saraiva LR (2019) Interspecific variation of olfactory preferences in flies, mice, and humans. Chemical senses 44:7-9

McClintock TS, Adipietro K, Titlow WB, Breheny P, Walz A, Mombaerts P, Matsunami H (2014) In vivo identification of eugenol-responsive and musconeresponsive mouse odorant receptors. The Journal of neuroscience : the official journal of the Society for Neuroscience 34:15669-15678

McClintock TS, Wang Q, Sengoku T, Titlow WB, Breheny P (2020) Mixture and concentration effects on odorant receptor response patterns in vivo. Chemical senses

Meister M (2015) On the dimensionality of odor space. eLife 4:e07865

Minor AV, Sakina NL (1973) Role of cyclic adenosine3',5'-monophosphate in olfactory reception. Neirofiziologiya 5:415-422

Miyamichi K, Serizawa S, Kimura HM, Sakano H (2005) Continuous and overlapping expression domains of odorant receptor genes in the olfactory epithelium determine the dorsal/ventral positioning of glomeruli in the olfactory bulb. The Journal of neuroscience : the official journal of the Society for Neuroscience 25:3586-3592

Morrison EE, Costanzo RM (1992) Morphology of olfactory epithelium in humans and other vertebrates. Microsc Res Tech 23:49-61

Münch D, Schmeichel B, Silbering AF, Galizia CG (2013) Weaker Ligands Can Dominate an Odor Blend due to Syntopic Interactions. Chemical senses 38:293304 
Nagai MH, Armelin-Correa LM, Malnic B (2016) Monogenic and Monoallelic Expression of Odorant Receptors. Mol Pharmacol 90:633-639

Nagashima A, Touhara K (2010) Enzymatic conversion of odorants in nasal mucus affects olfactory glomerular activation patterns and odor perception. The Journal of neuroscience : the official journal of the Society for Neuroscience 30:16391-16398

Nara K, Saraiva LR, Ye X, Buck LB (2011) A large-scale analysis of odor coding in the olfactory epithelium. The Journal of neuroscience : the official journal of the Society for Neuroscience 31:9179-9191

Niimura Y, Matsui A, Touhara K (2014) Extreme expansion of the olfactory receptor gene repertoire in African elephants and evolutionary dynamics of orthologous gene groups in 13 placental mammals. Genome Res 24:1485-1496

Oka Y, Nakamura A, Watanabe H, Touhara K (2004a) An odorant derivative as an antagonist for an olfactory receptor. Chemical senses 29:815-822

Oka Y, Omura M, Kataoka H, Touhara K (2004b) Olfactory receptor antagonism between odorants. Embo J 23:120-126

Omura M, Mombaerts P (2015) Trpc2-expressing sensory neurons in the mouse main olfactory epithelium of type B express the soluble guanylate cyclase Gucy1b2. Mol Cell Neurosci 65:114-124

Ottoson D (1954) Sustained potentials evoked by olfactory stimulation. Acta Physiologica Scandinavica 32:384-386

Pace U, Hanski E, Salomon Y, Lancet D (1985) Odorant-sensitive adenylate cyclase may mediate olfactory reception. Nature 316:255 - 258

Pauling L (1946) Molecular architecture and biological reactions. Chem Eng News 24:1375-1377

Peterlin Z, Li Y, Sun G, Shah R, Firestein S, Ryan K (2008) The importance of odorant conformation to the binding and activation of a representative olfactory receptor. Chem Biol 15:1317-1327

Pevsner J, Sklar P, Snyder S (1986) Odorant-binding protein: localization to nasal glands and secretions. PNAS 83:4942-4946

Pfister P, Smith BC, Evans BJ, Brann JH, Trimmer C, Sheikh M, Arroyave R, Reddy G, Jeong HY, Raps DA, Peterlin Z, Vergassola M, Rogers ME (2020) Odorant
Receptor Inhibition Is Fundamental to Odor Encoding. Curr Biol 30:2574-2587 e2576

Poivet E, Peterlin Z, Tahirova N, Xu L, Altomare C, Paria A, Zou DJ, Firestein S (2016) Applying medicinal chemistry strategies to understand odorant discrimination. Nature communications 7:11157

Poivet E, Tahirova N, Peterlin Z, Xu L, Zou DJ, Acree T, Firestein S (2018) Functional odor classification through a medicinal chemistry approach. Sci Adv 4:eaao6086

Ramón y Cajal S (1892) Nuevo concepto de la Histología de los centros nerviosos. Conferencia III. . Rev Cienc Méd Barc 457-476

Reddy G, Zak JD, Vergassola M, Murthy VN (2018) Antagonism in olfactory receptor neurons and its implications for the perception of odor mixtures. eLife 7:

Ressler KJ, Sullivan SL, Buck LB (1993) A zonal organization of odorant receptor gene expression in the olfactory epithelium. Cell 73:597-609

Rodriguez-Gil DJ, Bartel DL, Jaspers AW, Mobley AS, Imamura F, Greer CA (2015) Odorant receptors regulate the final glomerular coalescence of olfactory sensory neuron axons. Proceedings of the National Academy of Sciences of the United States of America 112:5821-5826

Rospars JP, Lansky P, Chaput M, Duchamp-Viret P (2008) Competitive and noncompetitive odorant interactions in the early neural coding of odorant mixtures. The Journal of neuroscience : the official journal of the Society for Neuroscience 28:2659-2666

Saito H, Chi Q, Zhuang H, Matsunami H, Mainland JD (2009) Odor coding by a Mammalian receptor repertoire. Sci Signal 2:ra9

Sanz G, Schlegel C, Pernollet JC, Briand L (2005) Comparison of odorant specificity of two human olfactory receptors from different phylogenetic classes and evidence for antagonism. Chemical senses 30:69-80

Saraiva LR, Ahuja G, Ivandic I, Syed AS, Marioni JC, Korsching SI, Logan DW (2015a) Molecular and neuronal homology between the olfactory systems of zebrafish and mouse. Scientific reports 5:11487

Saraiva LR, Ibarra-Soria X, Khan M, Omura M, Scialdone A, Mombaerts P, Marioni JC, Logan DW (2015b) Hierarchical deconstruction of mouse olfactory sensory neurons: from whole mucosa to single-cell RNA-seq. Scientific reports 5:18178 
Saraiva LR, Riveros-McKay F, Mezzavilla M, AbouMoussa EH, Arayata CJ, Makhlouf M, Trimmer C, Ibarra-Soria X, Khan M, Van Gerven L, Jorissen M, Gibbs M, O’Flynn C, McGrane S, Mombaerts P, Marioni JC, Mainland JD, Logan DW (2019) A transcriptomic atlas of mammalian olfactory mucosae reveals an evolutionary influence on food odor detection in humans. Science Advances 5:eaax0396

Sato-Akuhara N, Horio N, Kato-Namba A, Yoshikawa K, Niimura Y, Ihara S, Shirasu M, Touhara K (2016) Ligand Specificity and Evolution of Mammalian Musk Odor Receptors: Effect of Single Receptor Deletion on Odor Detection. Journal of Neuroscience 36:44824491

Sato T, Hirono J, Tonoike M, Takebayashi M (1994) Tuning specificities to aliphatic odorants in mouse olfactory receptor neurons and their local distribution. J Neurophysiol 72:2980-2989

Serizawa S, Miyamichi K, Nakatani H, Suzuki M, Saito M, Yoshihara Y, Sakano H (2003) Negative feedback regulation ensures the one receptor-one olfactory neuron rule in mouse. Science 302:2088-2094

Sharma A, Kumar R, Aier I, Semwal R, Tyagi P, Varadwaj P (2019) Sense of Smell: Structural, Functional, Mechanistic Advancements and Challenges in Human Olfactory Research. Curr Neuropharmacol 17:891-911

Shirokova E, Schmiedeberg K, Bedner P, Niessen H, Willecke K, Raguse JD, Meyerhof W, Krautwurst D (2005) Identification of specific ligands for orphan olfactory receptors. $G$ protein-dependent agonism and antagonism of odorants. J Biol Chem 280:11807-11815

Shykind BM, Rohani SC, O'Donnell S, Nemes A, Mendelsohn M, Sun Y, Axel R, Barnea G (2004) Gene switching and the stability of odorant receptor gene choice. Cell 117:801-815

Sicard G (1985) Olfactory discrimination of structurally related molecules: Receptor cell responses to camphoraceous odorants. Brain Res 326:203-212

Sicard G, Holley A (1984) Receptor cell responses to odorants: similarities and differences among odorants. Brain Res 292:283-296

Skouby AP, Zilstorff-Pedersen K (1954) The influence of acetyl-choline like substances. Menthol and Strychnine on olfactory receptors in man. Acta Physiologica Scandinavica 252 - 258
Spehr M, Gisselmann G, Poplawski A, Riffell JA, Wetzel CH, Zimmer RK, Hatt H (2003) Identification of a testicular odorant receptor mediating human sperm chemotaxis. Science 299:2054-2058

Sviridenko PA (1951) Theoretical differences on the rôle of olfactory receptors in rodents and their practical deflection. Zool Zhurnal 30:344 - 351

Tan L, Li Q, Xie XS (2015) Olfactory sensory neurons transiently express multiple olfactory receptors during development. Mol Syst Biol 11:844

Tan L, Xie XS (2018) A Near-Complete Spatial Map of Olfactory Receptors in the Mouse Main Olfactory Epithelium. Chemical senses 43:427-432

Tegoni M, Pelosi P, Vincent F, Spinelli S, Campanacci V, Grolli S, Ramoni R, Cambillau C (2000) Mammalian odorant binding proteins. Biochim Biophys Acta 1482:229-240

Tian H, Ma M (2008) Activity plays a role in eliminating olfactory sensory neurons expressing multiple odorant receptors in the mouse septal organ. Mol Cell Neurosci $38: 484-488$

Tietjen I, Rihel J, Dulac CG (2005) Single-cell transcriptional profiles and spatial patterning of the mammalian olfactory epithelium. Int J Dev Biol 49:201207

Tietjen I, Rihel JM, Cao Y, Koentges G, Zakhary L, Dulac C (2003) Single-cell transcriptional analysis of neuronal progenitors. Neuron 38:161-175

Vassar R, Ngai J, Axel R (1993) Spatial segregation of odorant receptor expression in the mammalian olfactory epithelium. Cell 74:309-318

von der Weid B, Rossier D, Lindup M, Tuberosa J, Widmer A, Col JD, Kan C, Carleton A, Rodriguez I (2015) Large-scale transcriptional profiling of chemosensory neurons identifies receptor-ligand pairs in vivo. Nat Neurosci 18:1455-1463

Xu L, Li W, Voleti V, Zou DJ, Hillman EMC, Firestein $S$ (2020) Widespread receptor-driven modulation in peripheral olfactory coding. Science 368 :

Young JM, Shykind BM, Lane RP, Tonnes-Priddy L, Ross JA, Walker M, Williams EM, Trask BJ (2003) Odorant receptor expressed sequence tags demonstrate olfactory expression of over 400 genes, extensive alternate splicing and unequal expression levels. Genome Biol 4:R71 
Zak JD, Reddy G, Vergassola M, Murthy VN (2020) Antagonistic odor interactions in olfactory sensory neurons are widespread in freely breathing mice. Nature communications 11:3350

Zapiec B, Mombaerts P (2020) The Zonal Organization of Odorant Receptor Gene Choice in the Main Olfactory Epithelium of the Mouse. Cell reports 30:4220-4234 e4225

Zhang X, Firestein S (2002) The olfactory receptor gene superfamily of the mouse. Nat Neurosci 5:124-133

Zhang X, Rogers M, Tian H, Zou DJ, Liu J, Ma M, Shepherd GM, Firestein SJ (2004) High-throughput microarray detection of olfactory receptor gene expression in the mouse. Proceedings of the National Academy of Sciences of the United States of America 101:14168-14173 